LBL- -22416

DE87 003638

\title{
TOLERANCE DOSES FOR TREATMENT PLANNING
}

\author{
John T. Lyman \\ Lawrence Berkeley Laboratory \\ University of California \\ Berkeley, CA 94720
}

October 1985

DISCLAIMER

This report was prepared as an account of work sponsored by an agency of the linted Siet.. Government. Neither the United States Government nor any agency thereof, nor sny of th=ir employees. makes any warranty, express or implied, or assumes any legal liabilsty of respons. bility for the accuracy, completeness, or usefulness of any information. apparatus, product, or process disclosed, or represents that its use would not infringe privately owned rights Refer. ence herein to any specilic commercial product, process, or service by trade name. trademark. manufacturet, or otherwise does not necessarily constilute of imply its endorsement, recom. mendation, or favoring by the United States Government of any agency thereof The views and opinions of authors expressed herein do not necessarily state or reflect thrse of the United States Government or any agency thereof. 


\section{TABLE OF NORMAL TISSUE TOLERANCES}

Data for the tolerance of normal tissues or organs to (low-LET) radiation has been compiled from a number of sources (1-7) which are referenced at the end of this document. These data are presented in Table I.

This tolerance dose data are ostensibiy for uniform irradiation of all or part of an organ, and are for either $5 \%\left(\mathrm{TD}_{5}\right)$ or $50 \%\left(\mathrm{TD}_{50}\right)$ complication probability. The "size" of the irradiated organ is variously stated in terms of the absolute volume or the fraction of the organ volume irradiated, or the area or the length of the treatment field.

The accuracy of these data is questionable. Much of the data represents doses that one or several experienced therapists have estimated could be safely given (i.e. data from Rubin and data from the Treatment Planning Intercomparison survey) rather than quantilative analyses of clinical observations. Because these data have been obtained from multiple sources with possible different criteria for the definition of a complication, there are sometimes different values for what is apparently the same endpoint. The data from some sources shows a tendancy to be quantized in $5 \mathrm{~Gy}$ increments. This reflects the size of possible round off errors.

It is believed that all these data have been accumulated without the benefit of 3-D dose distributions and therefore the estimates of the size of the volume and/or the uniformity of the irradiation may be less accurate than is now possible.

The data in the table are for "conventional" fractionation schedules (1.8-2.0 Gy per fraction and 5 fractions per week), assume relatively normal physiologic function before irradiation, and assume there to be no adjuvant therapy. The extrapolation to other fractionation schedules (8) and the modification of these tolerances when there is compromised function or when adjuvant therapy is given are important problems which need to be addressed. 


\section{USE OF TABLE I}

The data of Table I are not intended to be used for the treatment of patients, but as a guideline for the conduct of comparative treatment planning excercises.

This table has two potential applications: First and most simply, as a set of tolerance doses which can be referred to when drawing up a protocol for treatment planning of a particular disease in which case the table values can be interpreted as upper limits on dose which the planner should attempt to respect. Second and more quantitatively, one would like to be able to estimate a complication probability for each normal tissue and end-point of interest - in which case the table values can be considered to be data to which any model of normal tissue complication probability should conform.

\section{INTERPOLATION (AND EXTRAPOLATION) OF THE DATA}

How may the data of Table I be extended to predict the complication probability when the dose to an (unifonnly) irradiated volume is different from the few cases tabulated? Obviously, to do this, some model of the variation of normal tissue complication probability with both volume and dose must be implicitly or explicitly assumed. (Even an "eyeball" interpolation between two points implicitly assumes some smoothness criterion.)

Many authors (9-13) have suggested a simple model for the dependence on irradiated volume (or other size parameter) of the dose to achieve a specified complication, namely a power-law relationship of the form:

$$
\mathrm{TD}(\mathbf{v})=\mathrm{TD}(1) * \mathbf{v}^{-\mathbf{n}}
$$

where TD stands for tolerance dose, $v$ is the fraction of the volume (or area or length) of an organ irradiated (or the ratio of the size of irradiated tissue to some reference size) and $\mathbf{n}$ is a size dependence parameter whose value is determined by the particular organ and the size dimension (volume, area or length) of concern.

While an areal or linear characterization of the irradiated tissue is functionally appropriate for some tissues, such as esophagus, skin or spinal cord for example, it is much simpler to make an analysis of a treatment plan based on the irradiated volume, and for many geometries the other size 


\section{LBL- 22416}

parameters tend to scale with volume. Therefore, except for skin, all organ and tissue size dependences are considered to convertible to volume dependences. The tolerance doses in Table I relate to situations where the irradiated normal tissue is uniformily irradiated. The data was probably derived from the most commonly used treatment plans which are assumed to be either parallel opposed ports or four-field box plans using photon radiation. For small field sizes the irradiated volume can be significantly different depending upon the treatment plan; this can lead to possible errors in assigning a value to the parameter $n$.

The dependence of complication probability on dose (for fixed volume) is considered by many authors to have a sigmoidal shape (2,13-16). This can be represented with sufficient accuracy by one of a number of two-parameter expressions of which the most common are the logistic function and the error function. The two free parameters for such curves, namely the slope (or slandard deviation) and $\mathrm{TD}_{50}$ (dose to achieve $50 \%$ complication), can be fit by two data points - such as the doses to achieve $5 \%$ and $50 \%$ complication.

A three-parameter model which connects the three variables of interest (complication probability (P), dose (D) and volume (V)) has been developed. The expression used is as follows:

$$
P=\frac{1}{\sqrt{2 \pi}} \int_{-\infty}^{t_{\max }} \mathrm{e}^{-t^{2} / 2} \mathrm{dt}
$$

where $\left.t=\left(D-T_{50}(V)\right) / \sigma(V)\right)$ and $\sigma(V)=m * T_{50}(V)$. Equation $l$ is used to obtain $T_{50}(V)$ and $\mathbf{m}$ is the third free parameter which is to be determined by the data.

This formula is a combination of the power law dose-volume relationship (equation 1) and an error function representation of the complication-dose relationship and gives back these equations if complication probability or volume, respectively, are held constant.

Figure 1 shows a perspective display of the 3-D surface described by equation 2 for the heart. Figures 2, 3 and 4 show the more conventional 2-D cuts through the 3-D surface. Figure 2, is the familiar sigmoidal relationship between complication probabilities and dose, while Figure 3 which 
shows the dependence of dose on volume for fixed complication, is just the familiar power-law relationship of equation 1. Figure 4 show how the complication probability changes with change of the irradiated volume for three fixed dose levels.

Select data of Table I have been "fit" by choosing values for the three parameters of equation 2. In many instances there are insufficient data to determine the three parameters at all, or with reasonable accuracy. Therefore some simplifying assumptions have been made, namely:

1. The parameter $\mathbf{m}$, which is the standard deviation of the $\mathbf{P}$ vs. dose sigmoid curve in units of $\mathrm{TD}_{50}(\mathrm{~V})$, is assumed to be the same for all tissues and to be equal to 0.1 . This assumption in effect reduces the three parameter equation to an equation with only two free parameters.

2. When a close fit to all points was not achieved, the selection of parameters favored a good fit to the $5 \%$ complication probability data and larger volume data.

3. The parameter $\mathrm{TD}_{50}$ was variously taken directly from the data of Table I, or was biased in order to fit the $\mathrm{TD}_{5}$ data (necessary because $\mathrm{m}$ was held constant at 0.1 ). Initial estimates were sometimes based on an extrapolation from a datum point to the reference volume, using equation 1, when data at the reference volume were lacking.

Table II lists the selected values of the three parameters of equation 2. Brain stem is a special tissue which does not appear in Table I but is listed in Table II. For whole train irradiation, the brain stem is not assumed to be more sensitive than the remaining brain, however it is assigned a small value for the volume dependence which will make it effectively a more critical target per unit volume for smaller volumes. A number of tissues have cata at only a single volume; in these cases the parameter $\mathbf{n}$ was chosen to have a low value (i.e. small volume dependence), this is a conservative approach since it is expected to predict a tolerance dose smaller than the true value for the smaller volumes. The parameter $\mathbf{n}$ for skin is meant to be applied, not to a partial volume, but to the size of the equivalent square in decimeters. This is numerically the same as the ratio of the size of the 
equivalent square to the reference size of $10 \mathrm{~cm}\left(100 \mathrm{~cm}^{2}\right)$. The value for $n$ was chosen as a compromise value based on values from references 11-13.

While all these approximations may be a little troubling, they do not hinder the use of the data provided the crude nature of the fit is kept in mind. The parameters of Table II are just one set from several which could have been obtained, depending upon which values in Table I were of the most concern. In comparing two or more treatment plans, their ranking, with respect to their relative probabilities of damage to a normal structure, will be relatively insensitive to the choice of parameters if the same set of parameters is used for all the plans. All values in this table are preliminary and should not be taken as definitive. The purpose of this table is to provide a set of parameters which can be used in conjunction with equation 2 to model the late response of the selected normal tissues to radiation for treatment planning intercomparisons only.

Obviously, these fitting proceedures are an ad hoc and relatively crude way of establishing the parameters of equation 2. The justification of the selected values must lie primarily in the accuracy with which the resulting model represents the data of Table I. Table III shows the values of $\mathrm{TD}_{5}$ and $\mathrm{TD}_{50}$, calculated from equation 2 using the parameters of Table II, and corresponding data of Table $\mathrm{I}$ for comparison. By and large the correspondence is excellent. When comparing the calculated data to the fitted data, there are no instances where the difference between a calculated value and the corresponding data point was more than $5 \mathrm{~Gy}$. The quality of the data probably does not warrant efforts to use more or different parameters or different models. This table is included to indicate which data from Table I was considered to be most relavent for treatment planning intercomparisons. Other researchers may question the parameters and may wish to use different values. Based on the experience in questioning radiation oncologist colleagues $I$ feel that most would choose tolerance doses to be within \pm 5 Gy of these values. One must remember that the data generally do not come from a scientific stucy of the incidence of complications; rather, in the case of the $\mathrm{TD}_{5}$, these are 
doses that a number of experienced therapists have considered to be relatively safe.

Clearly, equation 2 must be used with extreme caution when extrapolating to conditions which are significantly outside those for which data are available - particularly when considering small volumes.

\section{NON-UNIFORM IRRADIATION}

The estimation of normal tissue complication when the tissue or organ is non-uniformily irradiated is both essential to the task of evaluating any practical treatment plan, and takes one well out of the range of quantitative clinical data. One approach to collect the needed data is to compare dose-volume histograms of patients with and without complications (17). Another way to make such an estimation is through a model. Such a model has been developed, using dose-volume histograms to characterize the dose distribution. Details of this model are presented elsewhere $(18,19)$. 


\section{Table I}

\section{CLASS I (fatal or severe morbidity) ORGANS}

$\mathrm{TD}_{5} \quad \mathrm{TD}_{50} \quad$ 'Size' Note

(Gy) (Gy')

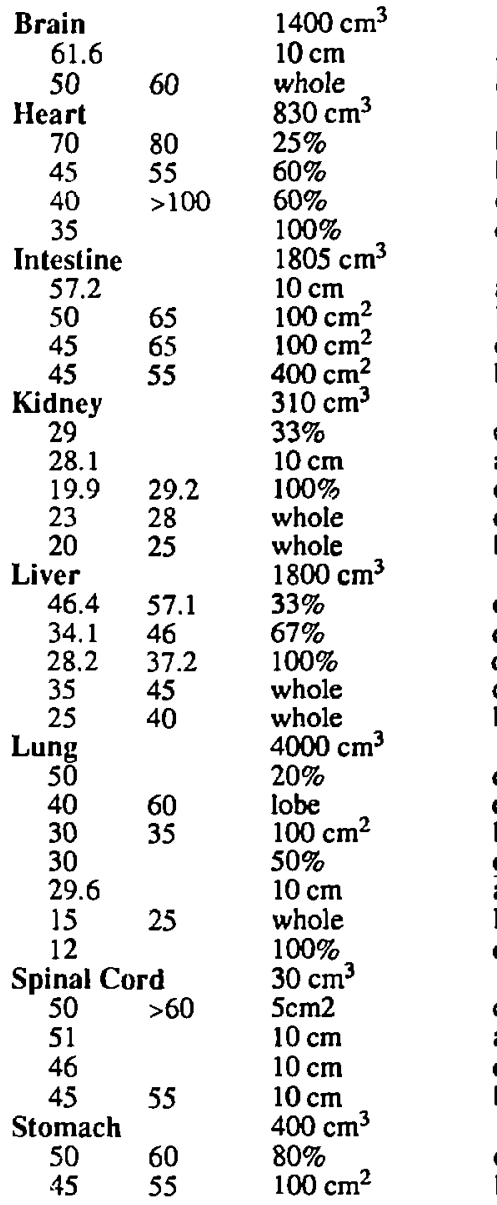

\section{Comment}

infarction, necrosis

a

b

$n=0.24(f)$

pericarditis and pancarditis

b

b

c

d

ulcer, perforation, hemorrhage

$\mathrm{n}=0.22$ (f)

b

c

b

d

a

d

c

b

d

d

d

c

b

d

c

b

d

a

b

d

acute and chronic hepatitis

acute and chronic nephrosclerosis

$\mathrm{n}=0.13$ (f)

acute and chronic pneumonitis

$$
n=0.24 \text { (f) }
$$

infarction, necrosis

c

a $\quad n=0.13(f)$

d

b

d

ulcer, perforation, hemorrhage 
Table I (cont)

CLASS II (moderate to mild morbidity) ORGANS

\begin{tabular}{|c|c|c|c|c|}
\hline $\begin{array}{l}\mathrm{TD}_{5} \\
(\mathrm{~Gy})\end{array}$ & $\begin{array}{l}\mathrm{TD}_{50} \\
(\mathrm{~Gy})\end{array}$ & 'Size' & Note & Comment \\
\hline $\begin{array}{c}\text { Bladder } \\
70 \\
60 \\
60\end{array}$ & $\begin{array}{l}80 \\
80 \\
>70\end{array}$ & $\begin{array}{l}145 \mathrm{~cm}^{3} \\
\text { Base \& Neck } \\
\text { whole } \\
100 \%\end{array}$ & $\begin{array}{l}\mathrm{d} \\
\mathrm{e} \\
\mathrm{d}\end{array}$ & $\begin{array}{l}\text { contracture } \\
\text { stricture } \pm \text { ulcer }\end{array}$ \\
\hline $\begin{array}{r}\text { Bone } \\
60 \\
60\end{array}$ & $\begin{array}{l}100 \\
150\end{array}$ & $\begin{array}{l}10 \mathrm{~cm}^{2} \\
10 \mathrm{~cm}^{2}\end{array}$ & $\begin{array}{l}\text { e } \\
\text { c }\end{array}$ & \\
\hline Esophagu & & $40 \mathrm{~cm}^{3}$ & & ulceration, stricture \\
\hline $\begin{array}{c}60 \\
\text { Eye } \\
55\end{array}$ & $\begin{array}{l}75 \\
100\end{array}$ & $\begin{array}{l}75 \mathrm{~cm}^{2} \\
7.5 \mathrm{~cm}^{3}\end{array}$ & e & \\
\hline $\begin{array}{l}55 \\
50 \\
5 \\
\text { Endocrine }\end{array}$ & $\begin{array}{l}70 \\
>60 \\
12 \\
12\end{array}$ & $\begin{array}{l}100 \% \\
100 \% \\
\text { any }\end{array}$ & $\begin{array}{l}\mathrm{e} \\
\mathrm{e} \\
\mathrm{e}\end{array}$ & $\begin{array}{l}\text { retina } \\
\text { comea } \\
\text { lens }\end{array}$ \\
\hline $\begin{array}{c}\text { Endocrine } \\
45-50 \\
45\end{array}$ & $\begin{array}{l}\text { glands } \\
200-300\end{array}$ & & $\begin{array}{l}c \\
\text { e }\end{array}$ & $\begin{array}{l}\text { pituitary } \\
\text { pituitary }\end{array}$ \\
\hline $\begin{array}{c}\text { Femoral } \\
50\end{array}$ & $\begin{array}{l}\text { Head } \\
65\end{array}$ & (adult) & d & fracture, asceptic necrosis \\
\hline $\begin{array}{l}\text { Mandible } \\
65 \\
60\end{array}$ & 75 & $80 \%$ & $\begin{array}{l}\mathbf{g} \\
\mathbf{c}\end{array}$ & osteoradionecrosis \\
\hline$\underset{55}{\text { Optic Ner }}$ & $\begin{array}{l}\text { ve and } \mathrm{Ch} \\
65\end{array}$ & iasm & d & visual field cut, blindness \\
\hline $\begin{array}{c}\text { Parotid } \\
50 \\
50 \\
60\end{array}$ & $\begin{array}{l}70 \\
60 \\
70\end{array}$ & $\begin{array}{l}50 \mathrm{~cm}^{2} \\
100 \% \\
100 \%\end{array}$ & $\begin{array}{l}c \\
d \\
h\end{array}$ & lack of moisture on Shirmer strip \\
\hline $\begin{array}{l}\text { Rectum } \\
55 \\
\text { Skin }\end{array}$ & 80 & $100 \mathrm{~cm}^{2}$ & c & lack of moisture on Shirmer stinp \\
\hline 55 & 70 & $100 \mathrm{~cm}^{2}$ & b & acute and chronic dermatitis \\
\hline
\end{tabular}

Notes:
a. see reference 1
b. see reference 2
c. see reference 4
d. see reference 5
e. see reference 3
$f$. The parameter, $n$, in the comment column is the size factor of Cohen (1) and is used to derive tolerance doses for field sizes other than the given reference value

g. see reference 6

h. see reference 7

The volume given in the size column for the tissue is the volume given for the ICRU reference man $(70 \mathrm{~kg}$ ) and is included for comparision with calculated volumes from dose-volume histograms (converted from grams, assuming $\rho=1.0$, except for lung). 


\section{TABLE II}

$\begin{array}{lllll}\begin{array}{l}\text { Organ } \\ \text { or tissue }\end{array} & \text { TD }_{\text {s0 }} & \text { n } & \text { m } & \text { Note } \\ \text { Bladder } & 72 & 0.10 & 0.1 & \\ \text { Bone } & 70 & 0.05 & 0.1 & \text { a } \\ \text { Brain } & 64 & 0.20 & 0.1 & \\ \text { Brain Stem } & 64 & 0.05 & 0.1 & \text { a } \\ \text { Cauda equina } & 57.5 & 0.10 & 0.1 & \text { b } \\ \text { Esophagus } & 66 & 0.15 & 0.1 & \text { c,d } \\ \text { Eye } & 60 & 0.05 & 0.1 & \text { a } \\ \text { Femoral Head } & 62 & 0.05 & 0.1 & \text { a } \\ \text { Heart } & 41.9 & 0.50 & 0.1 & \\ \text { Intestine } & 55 & 0.10 & 0.1 & \\ \text { Kidney } & 29 & 0.15 & 0.1 & \\ \text { Liver } & 35 & 0.40 & 0.1 & \\ \text { Lung } & 22 & 0.65 & 0.1 & \\ \text { Mandible } & 77 & 0.05 & 0.1 & \\ \text { Optic Nerve } & 65 & 0.05 & 0.1 & \text { a } \\ \text { Parotid } & 72 & 0.05 & 0.1 & \text { a } \\ \text { Pituitary } & 54 & 0.05 & 0.1 & \text { a } \\ \text { Rectum } & 75 & 0.10 & 0.1 & \text { e } \\ \text { Skin } & 68 & 0.30 & 0.1 & \text { f } \\ \text { Spinal Cord } & 50 & 0.10 & 0.1 & \text { c } \\ \text { Stomach } & 55 & 0.35 & 0.1 & \end{array}$

Notes:
a. Very small volume dependence $(0.05)$ assumed; no supporting data
b. Assumed to have a radiosensitivity 1.15 times that of ccrd
c. This structure is assumed to have a cylindrical shape with a length of $25 \mathrm{~cm}$. Partial volumes are then related to this length; partial irradiation of the cross-section is not addressed.
d. Moderate volume dependence (0.15) assumed; no supporting data
e. Small volume dependence $(0.10)$ assumed; no supporting data
f. Dependence is for the side of an equivalent square relative to $10 \mathrm{~cm}$. 
TABLE III

\begin{tabular}{|c|c|c|c|c|c|c|c|c|}
\hline Organ & Vol. & $\begin{array}{l}\mathbf{T D}_{\mathbf{s}} \\
\text { calcd. } \\
\text { (Gy) }\end{array}$ & $\begin{array}{l}\text { TD }_{5} \\
\text { Table I } \\
\text { (Gy) }\end{array}$ & $\begin{array}{l}\text { Diff. } \\
\text { (Gy) }\end{array}$ & $\begin{array}{l}T_{\text {sp }} \\
\text { calcd. } \\
\text { (Gy) }\end{array}$ & $\begin{array}{l}\mathrm{TD}_{50} \\
\text { Table I } \\
\text { (Gy) }\end{array}$ & $\begin{array}{l}\text { Diff: } \\
\text { (Gy) }\end{array}$ & Notes \\
\hline Class I Organs & & & & & & & & \\
\hline Brain & $\begin{array}{l}0.5 \\
1.0\end{array}$ & $\begin{array}{l}61.4 \\
53.5\end{array}$ & $\begin{array}{l}61.6 \\
50\end{array}$ & $\begin{array}{r}0.2 \\
-3.5\end{array}$ & $\begin{array}{l}73.5 \\
64\end{array}$ & 60 & -4.0 & $\begin{array}{l}a \\
b\end{array}$ \\
\hline Intestine & $\begin{array}{l}0.25 \\
1.0\end{array}$ & $\begin{array}{l}52.8 \\
46\end{array}$ & $\begin{array}{l}50 \\
45\end{array}$ & $\begin{array}{l}-2.8 \\
-1.0\end{array}$ & $\begin{array}{l}63.2 \\
55\end{array}$ & $\begin{array}{l}65 \\
55\end{array}$ & $\begin{array}{l}1.8 \\
0.0\end{array}$ & $\begin{array}{l}f \\
g\end{array}$ \\
\hline Heart & $\begin{array}{l}0.25 \\
0.6 \\
1.0\end{array}$ & $\begin{array}{l}70 \\
45.2 \\
35\end{array}$ & $\begin{array}{l}70 \\
45 \\
35\end{array}$ & $\begin{array}{r}0.0 \\
-0.2 \\
0.0\end{array}$ & $\begin{array}{l}83.8 \\
54.1 \\
41.9\end{array}$ & $\begin{array}{l}80 \\
55\end{array}$ & $\begin{array}{r}-3.8 \\
0.9\end{array}$ & \\
\hline Kidney & $\begin{array}{l}0.33 \\
1.0\end{array}$ & $\begin{array}{l}28.8 \\
242\end{array}$ & $\begin{array}{l}29 \\
20\end{array}$ & $\begin{array}{r}0.2 \\
-4.2\end{array}$ & 29 & 29 & 00 & \\
\hline Liver & $\begin{array}{l}0.33 \\
0.67 \\
1.0\end{array}$ & $\begin{array}{l}45.6 \\
34.3 \\
29.2\end{array}$ & $\begin{array}{l}46.4 \\
34.1 \\
28.2\end{array}$ & $\begin{array}{r}0.8 \\
-0.2 \\
-1.0\end{array}$ & $\begin{array}{l}54.7 \\
41.1 \\
35\end{array}$ & $\begin{array}{l}57.1 \\
46 \\
37.2\end{array}$ & $\begin{array}{l}2.4 \\
4.9 \\
2.2\end{array}$ & \\
\hline Lung & $\begin{array}{l}0.2 \\
0.5 \\
1.0\end{array}$ & $\begin{array}{l}52.3 \\
28.8 \\
18.4\end{array}$ & $\begin{array}{l}50 \\
30 \\
15\end{array}$ & $\begin{array}{r}-2.3 \\
1.2 \\
-3.4\end{array}$ & $\begin{array}{l}62.6 \\
34.5 \\
22\end{array}$ & $\begin{array}{l}35 \\
25\end{array}$ & $\begin{array}{l}0.5 \\
3.0\end{array}$ & $\mathrm{i}$ \\
\hline Spinal Cord & $\begin{array}{l}0.4 \\
0.8\end{array}$ & $\begin{array}{l}45.8 \\
42.7\end{array}$ & 45 & -0.8 & $\begin{array}{l}54.8 \\
51.1\end{array}$ & 55 & 0.2 & $c, d, e$ \\
\hline Stomach & $\begin{array}{l}0.8 \\
1.0\end{array}$ & $\begin{array}{l}49.7 \\
46\end{array}$ & $\begin{array}{l}50 \\
45\end{array}$ & $\begin{array}{r}0.3 \\
-1.0\end{array}$ & $\begin{array}{l}59.5 \\
55\end{array}$ & $\begin{array}{l}60 \\
55\end{array}$ & $\begin{array}{l}0.5 \\
0.0\end{array}$ & h \\
\hline \multicolumn{9}{|l|}{ Class 11 Organs } \\
\hline Bladder & $\begin{array}{l}0.4 \\
1.0\end{array}$ & $\begin{array}{l}65.9 \\
60.2\end{array}$ & $\begin{array}{r}65-70 \\
50\end{array}$ & 0.2 & $\begin{array}{l}78.9 \\
72\end{array}$ & $\begin{array}{r}75-80 \\
>70\end{array}$ & & \\
\hline Bone & 1.0 & 58.5 & 60 & 1.5 & 70. & & & \\
\hline $\begin{array}{l}\text { Esophagus } \\
\text { Eye }\end{array}$ & $\begin{array}{l}0.6 \\
1.0\end{array}$ & $\begin{array}{l}59.5 \\
50.1\end{array}$ & $\begin{array}{l}60 \\
50\end{array}$ & $\begin{array}{l}0.5 \\
0.1\end{array}$ & $\begin{array}{l}71.3 \\
60\end{array}$ & $\begin{array}{l}75 \\
60\end{array}$ & $\begin{array}{l}3.7 \\
0.0\end{array}$ & $\underset{k}{c, j}$ \\
\hline $\begin{array}{l}\text { Femoral } \\
\text { head }\end{array}$ & 1.0 & 51.8 & 50 & 1.8 & 62 & 65 & 3.0 & \\
\hline Mandible & 0.8 & 64.3 & 65 & 0.7 & 77 & 75 & -2.0 & \\
\hline Parotid & 1.0 & 60.2 & 60 & 0.2 & 72 & 70 & -2.0 & \\
\hline Rectum & 1.0 & 62.7 & 60 & 2.7 & 75 & 80 & 5.0 & \\
\hline Skin & 10 & 56.8 & 55 & -1.8 & 68 & 70 & 2.0 & 1 \\
\hline
\end{tabular}

Notes:

a. $10 \mathrm{~cm}$ field size. assumed to irradiate partial volume of 0.5 .

b. Full volume assumed to be related to field size of $14.1 \mathrm{~cm}$.

c. A linear structure with assumed length of $25 \mathrm{~cm}$.

d. "Table I" value calculated using $\mathbf{n}$ factor of Cohen.

e. Partial volume of 0.4 is equivalent to $10 \mathrm{~cm}$ length.

f. $500 \mathrm{~cm}^{2}$ beam area assumed to irradiate a partial volume of 0.25 .

g. Full volume is assumed to be treated with $2000 \mathrm{~cm}^{2}$ beam area.

h. Full volume is assumed to be treated with $100 \mathrm{~m}^{2}$ beam area.

i. $100 \mathrm{~cm}^{2}$ beam area assumed to cover 0.5 of a sirgle lung.

j. Partial volume of $n .6$ assumed to be related to $15 \mathrm{~cm}$ length.

k. Cornea or retina.

1. For a $100 \mathrm{~cm}^{2}$ field size. 


\section{Acknowledgements}

The aid of the participarts in the workshops on "Evaluation of Treatment Planning for Prartele Beam Radiotherapy" is greatly appreciated. Special thanks is given to Dr. Michael Coitein for his many suggestions related to the writing of this manuscript. This work was supported in part by the National Cancer Institu:e, National Institutes of Health, Pubic Health Services under Agreement No. Y0I-CM 20110 and the Offices of Health and Environmental Research, Office of Energy Research, U. S. Department of Energy under Contract DE-AC03-76SF0009d.

\section{ReFerences}

1. L. Cohen, Biophysical Models in Radiation Oncoiogy. CRC Press, Inc. Boca Raton, FL.. 1983.

2. P. Rubin, Clinical Oncology for Medical Students and Physicians. Amarican Cancer Society, 1983.

3. P. Rubin, R. A. Cooper, and T.L. Phillips, (Eds.), Radiation Biology and Radiasion Pothclogy Syllabus, Set R.T.I: Radiation Uncology, pp. 2-7, Am. College of Radiology, Chicago, 1975.

4. ICRP, Nonstochastic effects of ionizing radiation, ICRP Publication 41. Annals of ICRP 14, No. 3, 1984.

5. Private communications, Treatment Planning Intercomparison Survey and Questionaires: (October 1983-March. 1984)

6. R.B. Morrish, E. Chan, S. Siiverman, J. Meyer, K.K. Fu and D. Greenspan, $\mathrm{O}$ :ecenecrosis in patients irradiated for head and neck carcinoma. Cancer 47, 1980-1983 (19\%,1).

7. J.E. Marks, C.C. Davis, V.L. Gottsman, J.E. Purdy and F, Lee, The effects of radiation on parotid salivary function. Int. J. Radiat. Oncol. Biol. Phys. 7, 1013-1019 (1981).

8. G.W. Barendsen, Dose fractionation, dose rate and iso-effect relationships for normal tissue responses. Int. J. Radiat. Oncol. Riol. Phys. 8, 1981-1997 (1982).

9. H.R. Withers, H.D. Thames, and L.J. Peters, Dose fractionation and volume effects in normal tissues and tumors. Cancer Treatment Symposia 1, 75-83 (1984).

10. T.E. Schultheiss, C.G. Ortor, and R.A. Peck, Models in radiotherapy: Volume effects. Med. Phys. 10, 410-415 (1983).

11. C.F. von Essen, A spatial model of time-area relationships in radiation therapy. Radiol., 81, $881-883,(1963)$.

12. S.C. Prasad, Relation between tolerance dose and tredtment field size in radiation therapy. Med. Phys . 5, 431-433 (1978).

13. L. Cohen, The tissue factor in radiation oncology. Int. J.Ratiat. Oncol. Bial. Phys. 8, $1771-1774(1982)$. 
14. M. Goitein, The utility of computed tomography in radiation therapy: An estimate of outcome. Int. J. Radiat. Oncol. Biol. Phys. 5, 1799-1807 (1979).

15. J.E. Marks, Computed Tomography and Dose Optimization: Brain Tumors. In Computed Tomography in Radiarion Therapy (C.C. Ling, C.C. Rogers and R.J. Morton Eds.) Raven Press, New York pp 81-87, 1983.

16. E.H. Porter, The statistics of dose/cure relationships for irradiated tumors. Part I. Brit. J. Radiol. 53, 210-227 (1980).

17. J.E. Mizoe and C.F. von Essen, Complication probability analysis for late rectal reactions of patients treated with negative pions. In SIN Medical Newsletter Number 6,1984 (H. Blatuman, Ed.) Villigen, pp 23-25, 1985.

18. J.T. Lyman, Complication probabilities as assessed from dose-volume histograms. Radiat. Res. Suppl 8, S-13-S-19, 1985.

19. J.T. Lyman and A.B. Wolbarst, Optimization of radiation therapy, IIl: A method of assessing complications from dose-volume histograms. Int J Rad Oncol Biol Phys (in press, 1986). 


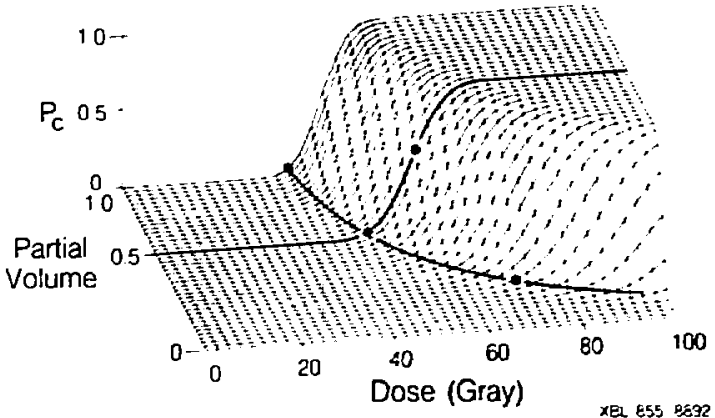

Figure 1. A perspective display of the 3-D surface describst by equation 2 for the heart using the parameters given in Table II.

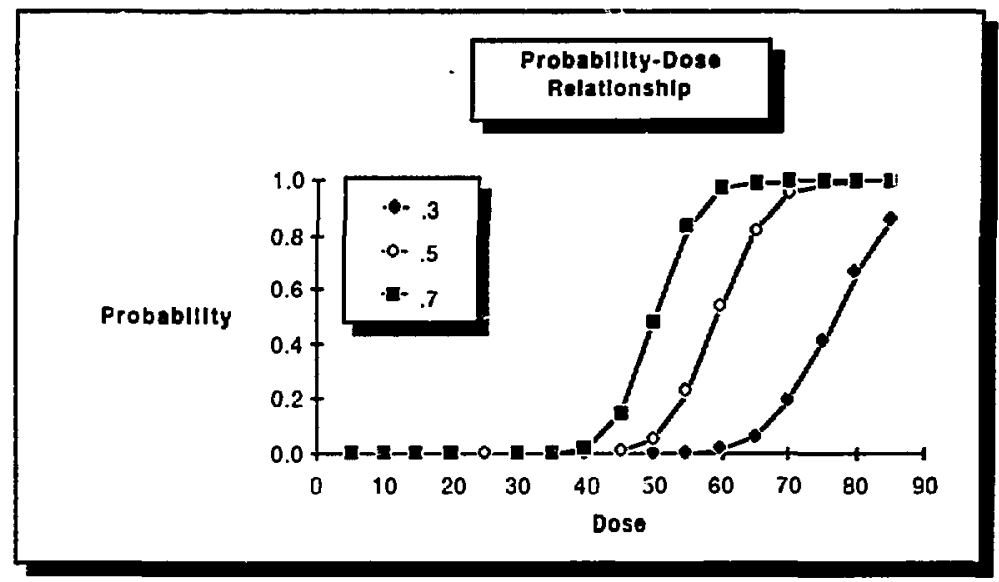

Figure 2. The sigmoidal relationship between complication probabilities and dose.The curves represent the relationship for three different irradiated partial volumes. Values were determined with equation 2 and the parameters for the heart from Table II. 


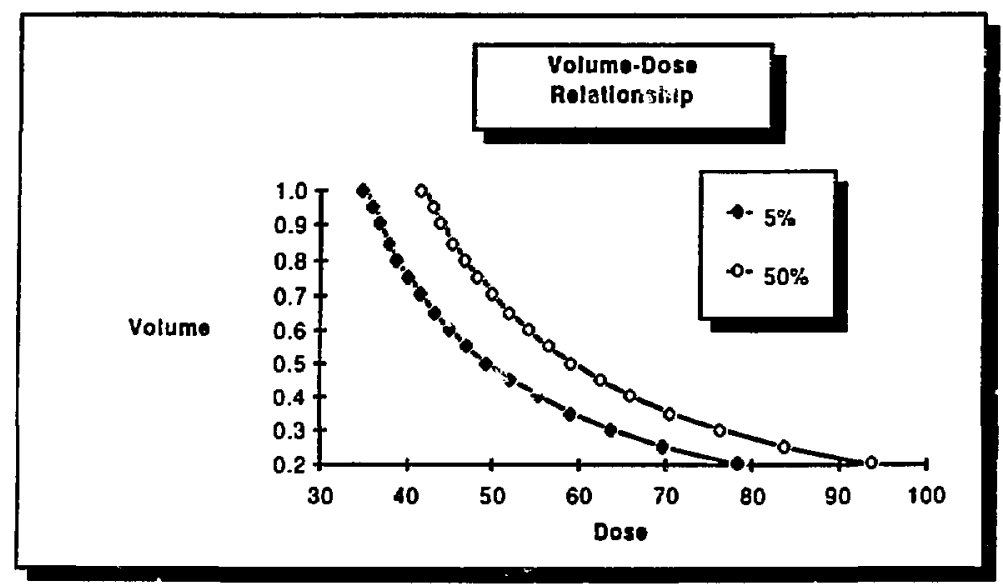

Figure 3. The dependence of dose on volume for 5 and $50 \%$ complication probabilities for the heart. This is the power-law relationship of equation 1, using parameters from Table II.

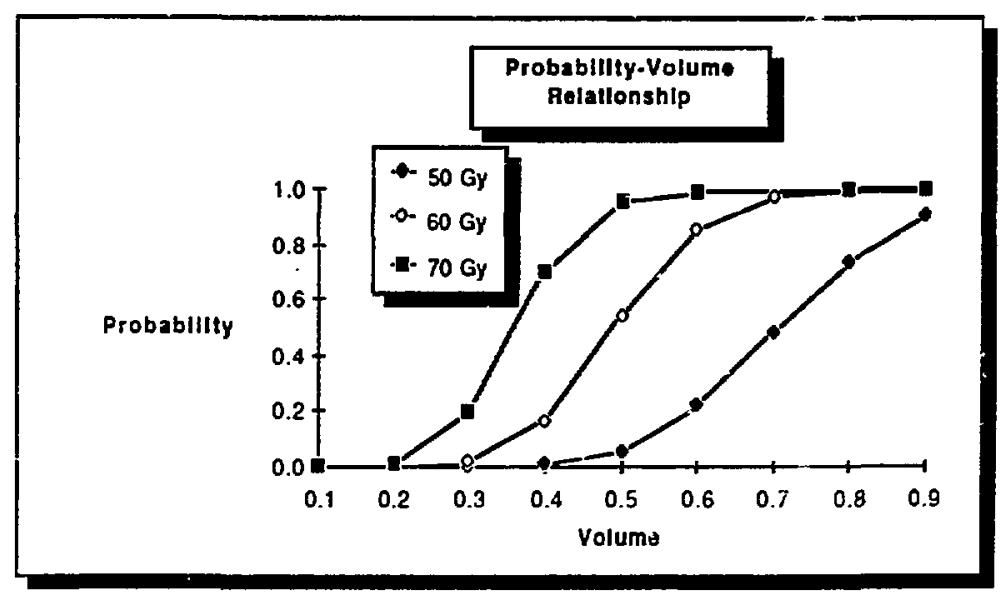

Figure 4. The relationship between the complication probability and partial volume for the heart at three different values of dose. 
This repon was done with. supporn from the Depariment of Energy. Any conclusions or opinions expressed in this report represent solely those of the aulhor(s) and noc neceswerily those of The Rezents of the University of Californin, the Lawrence Berkeley Laboratory or the Department of Energy.

Reference to a eompany or produet name does not imply approval of recommendation of the product by the University of California or the U.S. Department of Energy to the exclusion of others that may be suitable. 